\title{
Alzheimer's in post-industrial epoch
}

\author{
Alexander Kholmanskiy \\ Moscow State University of Medicine and Dentistry \\ st. Delegate, 20. Moscow, 127473, Russia, allexhol@ya.ru \\ https://orcid.org/0000-0001-8738-0189
}

\section{Highlights:}

- Mortality from Alzheimer's increases exponentially as countries develop

- Life expectancy after 55 years is proportional to the level of education

- Discrepancy between profession and man mentality is a risk factor for Alzheimer's

- Geography of Alzheimer's depends on influence of solar factors on mentality

\begin{abstract}
Study nature of epidemiological risk factors and patterns of distribution of mortality from Alzheimer's $\left(D_{A}\right)$ in 160 countries. Exponential Malthus model was used to construct adequate approximations of statistical data. Proportionality of average lifetime after 55 years (4t) to education

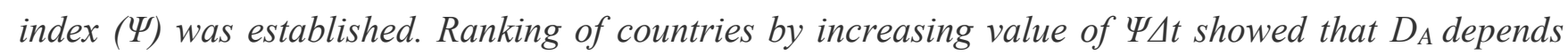
exponentially on $\Psi \Delta t$ and all countries can be divided into three groups in accordance with level of their economic development. In series of countries of low, medium and highly developed, their average values of $D_{A}$ increase exponentially. Growth of $D_{A}$ in developed countries in post-industrial epoch was explained by emergence of new risk factor Alzheimer's of mental nature. A mismatch of complexity or, on contrary, primitiveness of profession with level of mental development of worker, provokes development of chronic stress in him, fraught with pathologies of cognitive function metabolism in elderly.
\end{abstract}

Keywords: mortality; Alzheimer's; education; life expectancy; mentality; level of development. 


\section{Introduction}

Alzheimer's disease (AD) is the most common form of senile dementia in developed countries [1-3]. BA is considered a multifactorial disease and mutations of certain genes, the mechanism of which is not known, have a leading role in its development [4]. The epidemiological risk factors for the development of $\mathrm{AD}$ include age, genetic predisposition, cerebrovascular syndrome, diabetes mellitus $[5,6]$. The pathogenesis of $\mathrm{AD}$ begins to progress after 55-60 years, when the reproductive component of the hormonal background of brain metabolism weakens, controlled by the epiphysis and pituitary gland. In the same period, defective genes are activated and the protein metabolism of cerebral tissues is disturbed, leading to accumulation of amyloid and tau protein inside cells in the parenchyma and blood vessels of the brain. The deterioration of the rheological parameters of the brain's fluid systems leads to tissue hypoxia and the accumulation of chiral glucose in the blood, which leads to a decrease in the brain's energy potential and the kinetics of metabolic processes. Despite the enormous amount of empirical knowledge about $\mathrm{AD}$, the physicochemical nature and molecular mechanisms of the action of external and internal factors responsible for the etiology and pathogenesis of $\mathrm{AD}$ have not yet been established [2]. The absence of these data does not allow to purposefully develop effective and fairly harmless drugs for the prevention and treatment of asthma and dementia [3].

It should be noted that the reliability of the patterns of global epidemiology of AD is determined by the adequacy of statistical data on the prevalence and mortality of $\mathrm{AD}$ per 100 thousand population $\left(\mathrm{D}_{\mathrm{A}}\right)$ in different countries. Currently, the most accurate are the results of a systematic study of the global regional and national burden of Alzheimer's disease and other dementias for 2016, which takes into account the analysis of the burden of these diseases for 1990-2016 [1]. The scientific inadequacy of statistical data may lead to erroneous results in studies of the nature of the epidemiological risks of $\mathrm{AD}$ for a particular region or country. For example, in work [7] it was not possible to establish climatic and ecological justifications for the leadership of Finland in the global $\mathrm{D}_{\mathrm{A}}$ rating 
given on the website [8] (Figure 1b). However, according to [1], $\mathrm{D}_{\mathrm{A}}$ for Finland has a different meaning, which is close to $\mathrm{D}_{\mathrm{A}}$ for Greece, Spain and significantly less than for Italy and Japan (Figure 1a).

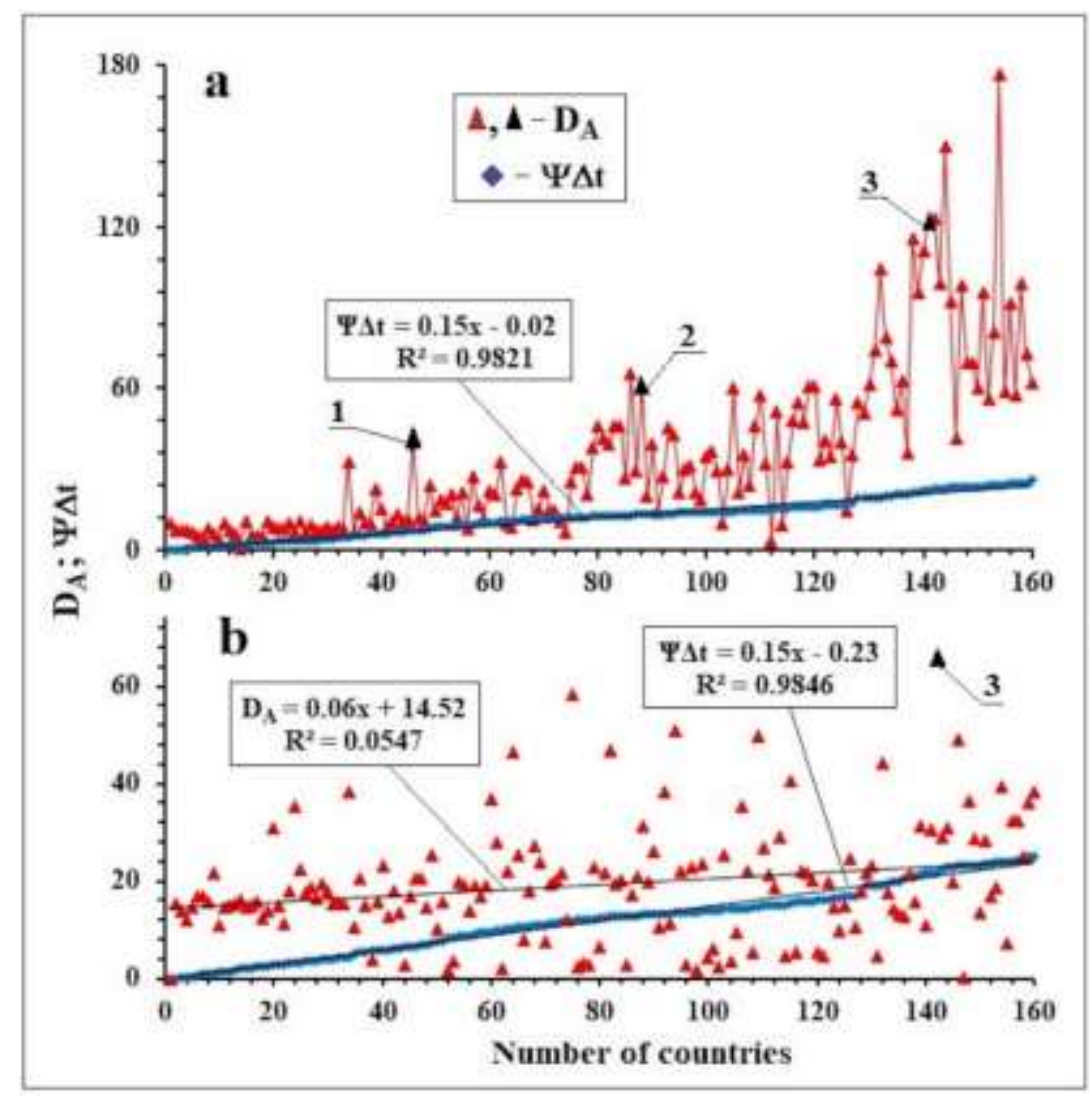

Figure 1. Country rankings and $D_{A}$ values by increasing $\Psi \Delta t$ ( $\Psi$ is the education index, $\Delta t$ is the average lifetime after 55 years). The sequence numbers of countries in the Table. Points (1) and (2) - $D_{A}$ for China and India are not considered Rural population, point (3) refers to Finland. Baseline data (a) from [1], (b) from [8].

Thus, the $\mathrm{D}_{\mathrm{A}}$ analysis carried out in [7] confirms that Finland has no pronounced regional and environmental specificity of the epidemiological risks of AD. The inadequacy of the $\mathrm{D}_{\mathrm{A}}$ rating in [8] can also be judged by the $\mathrm{D}_{\mathrm{A}}$ value for Japan, which, it turns out, is an order of magnitude smaller than the $\mathrm{D}_{\mathrm{A}}$ figured in $[1,9]$.

Due to the global nature of heliobiology [10] and differences in the energy of sapientation in the countries above and below $\sim 40^{\circ} \mathrm{nl}$. [11] when studying the biophysical nature of the epidemiological risks of asthma, the role of solar factors must be taken into 
account. The human body and the brain as a whole is an open water-containing biosystem capable of self-regulation in a narrow temperature range $(\mathrm{T}=309-310 \mathrm{~K})$ [12]. It is in this range that the anomalous properties of water ensure the stability of homeostasis and effective energy-informational exchange of the brain with the body and with the external environment.

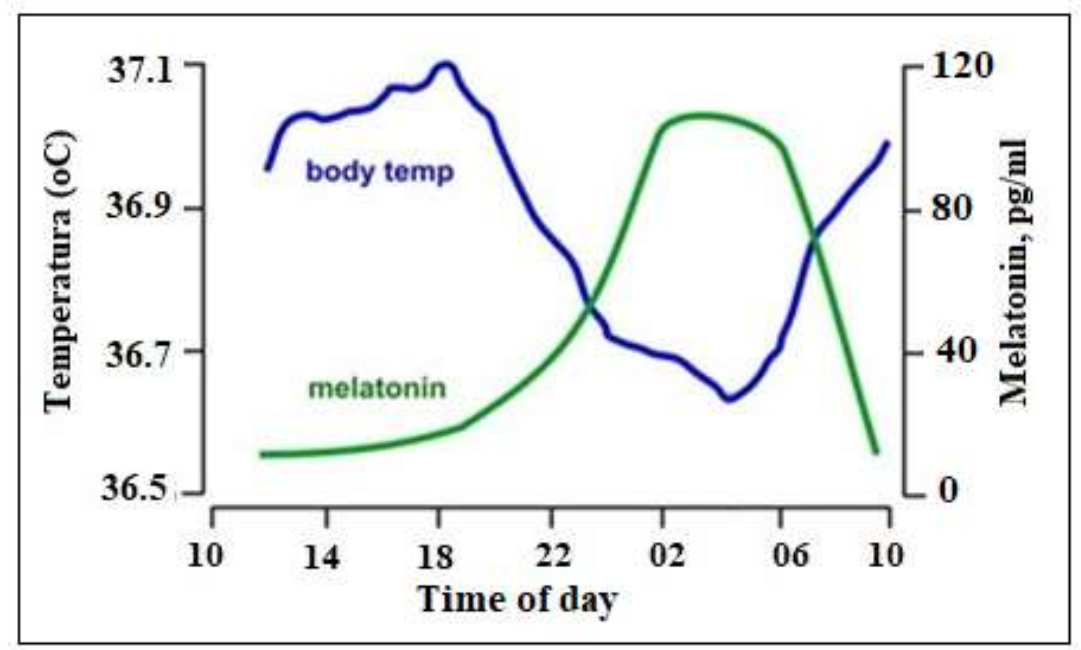

Figure 2. Daily variations in body temperature and melatonin levels in human blood. Figure, from [14].

In $[11,13]$, it was suggested that the specificity of the night period of the circadian rhythm determines the chiral factor $(\mathrm{CF})$ of a solar nature. In part, it is manifested in daily variations in plasma cortisol and melatonin levels [14]. Cortisol affects carbohydrate metabolism, increasing the concentration of glucose in the blood from 4 to 8 hours. Stress intensifies the production of cortisol, increasing the likelihood of diabetes. The maximum content of melatonin in the blood is observed in the middle of a normal night's sleep at 24 am (Figure 2).

It is possible that melatonin can inhibit the formation of amyloid plaques [15, 16]. Violations of the night sleep mode lead to a decrease in the effectiveness of CFSN action and melatonin biosynthesis [17], the deficiency of which can provoke a disorganization of the metabolism at the neurohumoral level [14, 17]. For example, people who systematically work at night increase the probability of the appearance of $\operatorname{AD}[15,16,18$, 19], diabetes [20], and also cancer of various organs at women [21, 22] and men [23]. The 
positive and negative effects of $\mathrm{CF}$ and other biophysical factors on the brain or its individual organs can be carried out directly or through sensory systems outside the range of their normal sensitivity. In mice, for example, they found a decrease in the number of amyloid plaques when exposed to sound vibrations at a frequency of $40 \mathrm{~Hz}$ [24]. Since this frequency resonates with the $\gamma$-rhythm of the brain, it is believed [25] that in a person with $\mathrm{AD}$ such a sound can inhibit the formation of amyloids. Such effects are possible due to the acoustic properties of the fluid media of the brain [26] and the resonant connection of its $\gamma$-rhythm with the activity of the neurons of the auditory system [27].

Considering the key role of glucose and proteins in the metabolism of a sleeping man's brain, [] suggested that their biosynthesis and activity regulates CF and its intensity depends on geography and seasonality.

Thus, it can be considered that hereditary or acquired distortions of the physicochemical bonds of the body with the external environment are the basis of the molecular mechanisms of the etiology and pathogenesis of diseases such as AD, oncology and diabetes. To substantiate this situation, in this paper, we studied the dependences of $\mathrm{AD}$ and $\mathrm{D}_{\mathrm{A}}$ on the characteristics of geography and climate, as well as on the level of education and average life expectancy of the population in 160 countries of the world. To identify the nature of the physical factor regulating the metabolism of the brain in the state of night sleep, we carry out daily and inter-seasonal monitoring of the optical activity of the dextran saline.

\section{Methods and materials}

The population loss $(\Delta N)$ from $A D$ in different countries for 2016 was taken from [1], and the total population of the countries $\left(\mathrm{N}_{\mathrm{o}}\right)$ from [28]. $\mathrm{D}_{\mathrm{A}}$ per 100,000 population was calculated by the formula:

$$
\mathrm{D}_{\mathrm{A}}=\left(10^{5} \Delta \mathrm{N}\right) / \mathrm{N}_{\mathrm{o}}
$$

Of the 190 countries in [1] left 160 countries for which there were values of the education index $(\Psi)$ [29] and average life expectancy $\left(t_{v}\right)$ in which there were more than 55 years [30]. Symptoms of AD begin to manifest themselves for men and women from 
$\sim 55$ years [1]. Taking this into account, we determined the temporal risk factor of AD $(\Delta \mathrm{t}$, years):

$$
\Delta \mathrm{t}=\mathrm{t}_{\mathrm{v}}-55 .
$$

Investigated a physiological solution of dextran with a molecular weight of from 30,000 to 40,000 ( $10 \mathrm{~g}$ of dextran and $0.9 \mathrm{~g}$ of $\mathrm{NaCl}$ per $100 \mathrm{ml}$ of water for injection). The angle of rotation of the polarization plane $\left(^{\circ}\right)$ of light (wavelength $589 \mathrm{~nm}$ ) was measured on a CM-3 circular polarimeter (measurement accuracy $\pm 0.02^{\circ}$, cuvette $2 \mathrm{dm}$ long). The measurements were carried out at room $\mathrm{T}\left(24^{\circ} \mathrm{C} \pm 1{ }^{\circ} \mathrm{C}\right)$.

Statistics on mortality from asthma in [1] are presented with a $95 \%$ uncertainty interval (95\% UI). For their processing and graphing used the program Microsoft Office Excel 2010.

\section{Results}

The value of $\Delta t$ is linearly dependent on $\Psi$ (Figure $3 \mathrm{a}$ ), and a decrease in the statistically average tv value due to $\mathrm{D}_{\mathrm{A}}$ is insignificant. Considering also the steady increase in tv with the development of countries, $\Psi \Delta \mathrm{t}$ can be considered a demographic parameter characterizing the contribution of the population over 55 years old to the country's intellectual potential. The ranking of $D_{A}$ and countries with $t_{v}>55$ years, by increasing values of $\Psi \Delta \mathrm{t}$ is presented in the Table and illustrated in Figure 1. It contains points 1) and 2) the values of $\mathrm{D}_{\mathrm{A}}$ for China and India, calculated without taking into account the share of rural (illiterate) population which for these countries amounted to $0.73 \mathrm{~N}_{\mathrm{o}}[31]$ and $0.43 \mathrm{~N}_{\mathrm{o}}$, respectively.

The cognitive abilities of a person mainly suffer from $\mathrm{AD}$, which to a certain extent characterizes the value of $\Psi$, as well as the interval $\Delta t$, an increase in which leads to an increase in $\mathrm{D}_{\mathrm{A}}$ [9]. The population mortality dynamics from $\mathrm{AD}$ is subject to the Malthus exponential model and can be formally described by the equation [11]:

$$
\mathrm{D}_{\mathrm{A}}=\left(10^{5} \Delta \mathrm{N}\right) / \mathrm{N}_{\mathrm{o}}=\mathrm{k} \Psi \Delta \mathrm{t},
$$

here $\mathrm{k}$ is a constant $\left(\mathrm{year}^{-1}\right)$. 


\section{Intelligence parameter $\left(\Psi \Delta t\right.$, years) and mortality rate $\left(D_{A}\right.$, patients per 100000$)$}

\begin{tabular}{|c|c|}
\hline № & Country \\
\hline 1 & Mozambique \\
\hline 2 & Guinea-Bissau \\
\hline 3 & South Sudan \\
\hline 4 & Cameroon \\
\hline 5 & Burundi \\
\hline 6 & Mali \\
\hline 7 & Burkina Faso \\
\hline 8 & Equatorial \\
\hline 9 & Guinea \\
\hline 10 & Niger \\
\hline 11 & Zimbabwe \\
\hline 12 & Uganda \\
\hline 13 & Benin \\
\hline 14 & Congo \\
\hline 15 & Djibouti \\
\hline 16 & Togo \\
\hline 17 & Eritrea \\
\hline 18 & Liberia \\
\hline 19 & Sudan \\
\hline 20 & Ethiopia \\
\hline 21 & Zambia \\
\hline 22 & Mauritania \\
\hline 23 & Yemen \\
\hline 24 & Papua New \\
\hline 25 & Haiti \\
\hline 26 & Kenya \\
\hline 27 & Malawi \\
\hline 28 & Ghana \\
\hline 29 & Comoros \\
\hline 30 & Rwanda \\
\hline 31 & Senegal \\
\hline 32 & Tanzania \\
\hline 33 & Pakistan \\
\hline 34 & Myanmar \\
\hline 35 & Madagascar \\
\hline 36 & Laos \\
\hline 37 & Namibia \\
\hline 38 & Solomon Islands \\
\hline 39 & Gabon \\
\hline 40 & Cambodia \\
\hline 41 & Botswana \\
\hline 42 & Guyana \\
\hline 43 & Bhutan \\
\hline 44 & Turkmenistan \\
\hline 45 & Nepal \\
\hline 46 & India \\
\hline 47 & Iraq \\
\hline 48 & Bangladesh \\
\hline 49 & North Korea \\
\hline 50 & Philippines \\
\hline 51 & Guatemala \\
\hline 52 & Indonesia \\
\hline 53 & Bolivia \\
\hline 54 & Vanuatu \\
\hline
\end{tabular}

\begin{tabular}{|c|c|c|c|}
\hline$\Psi \Delta t$ & $\mathbf{D}_{\mathbf{A}}$ & № & Country \\
\hline 0.04 & 9.67 & 55 & Honduras \\
\hline 0.1 & 7.04 & 56 & Tajikistan \\
\hline 0.2 & 7.41 & 57 & Morocco \\
\hline 0.2 & 7.57 & 58 & Egypt \\
\hline 0.7 & 6.32 & 59 & Uzbekistan \\
\hline 0.9 & 5.10 & 60 & Suriname \\
\hline 1 & 4.79 & 61 & Libya \\
\hline 1.1 & 7.61 & 62 & Salvador \\
\hline 1.3 & 5.91 & 63 & Belize \\
\hline 1.3 & 4.19 & 64 & Mongolia \\
\hline 1.4 & 10.23 & 65 & Nicaragua \\
\hline 1.6 & 7.26 & 66 & Paraguay \\
\hline 1.9 & 5.84 & 67 & Trinidad \& \\
\hline 1.9 & 0.70 & 68 & Kyrgyzstan \\
\hline 2.2 & 10.89 & 69 & Azerbaijan \\
\hline 2.3 & 5.26 & 70 & Dominic. \\
\hline 2.3 & 5.53 & 71 & Kazakhsta \\
\hline 2.5 & 5.40 & 72 & Fiji \\
\hline 2.7 & 10.52 & 73 & Palestine \\
\hline 2.9 & 8.71 & 74 & Kuwait \\
\hline 2.9 & 7.67 & 75 & Colombia \\
\hline 3.1 & 7.83 & 76 & Moldova \\
\hline 3.1 & 9.81 & 77 & Saint Luci \\
\hline 3.2 & 6.87 & 78 & Maldives \\
\hline 3.3 & 10.76 & 79 & Russia \\
\hline 3.4 & 6.78 & 80 & Thailand \\
\hline 3.5 & 8.96 & 81 & Tunisia \\
\hline 3.5 & 7.36 & 82 & Seychelles \\
\hline 3.9 & 7.19 & 83 & Vietnam \\
\hline 3.9 & 8.69 & 84 & Ukraine \\
\hline 4.1 & 7.27 & 85 & Samoa \\
\hline 4.4 & 8.57 & 86 & Slovenia \\
\hline 4.4 & 8.25 & 87 & Algeria \\
\hline 4.5 & 32.85 & 88 & China \\
\hline 5 & 6.62 & 89 & Peru \\
\hline 5.3 & 14.20 & 90 & Brazil \\
\hline 5.4 & 9.72 & 91 & Jordan \\
\hline 5.7 & 9.81 & 92 & Grenada \\
\hline 5.8 & 22.58 & 93 & Turkey \\
\hline 6.2 & 15.61 & 94 & Belarus \\
\hline 6.3 & 8.83 & 95 & Venezuela \\
\hline 6.5 & 10.71 & 96 & Tonga \\
\hline 6.6 & 13.00 & 97 & Macedonia \\
\hline 6.7 & 10.65 & 98 & Malaysia \\
\hline 6.9 & 11.60 & 99 & Ecuador \\
\hline 7 & 41.00 & 100 & Jamaica \\
\hline 7.2 & 11.74 & 101 & Mauritius \\
\hline 7.6 & 10.31 & 102 & Dominica \\
\hline 7.7 & 24.12 & 103 & Oman \\
\hline 8.4 & 14.56 & 104 & Mexico \\
\hline 8.5 & 18.87 & 105 & Serbia \\
\hline 8.6 & 17.62 & 106 & Iran \\
\hline 8.7 & 20.80 & 107 & Armenia \\
\hline 8.9 & 11.89 & 108 & Antig \\
\hline
\end{tabular}

\begin{tabular}{|c|c|c|c|}
\hline$\Psi \Delta t$ & $\mathbf{D}_{\mathbf{A}}$ & № & Country \\
\hline 9.4 & 21.5 & 109 & Bosnia Herzeg. \\
\hline 9.5 & 7.8 & 110 & Bulgaria \\
\hline 9.6 & 27.5 & 111 & Sri Lanka \\
\hline 9.7 & 16.6 & 112 & UAE \\
\hline 9.9 & 11.6 & 113 & Romania \\
\hline 10.1 & 22.1 & 114 & Bahrain \\
\hline 10.2 & 20.7 & 115 & Panama \\
\hline 10.5 & 32.6 & 116 & Georgia \\
\hline 10.6 & 10.0 & 117 & Uruguay \\
\hline 10.6 & 8.7 & 118 & Barbados \\
\hline 10.8 & 22.4 & 119 & Latvia \\
\hline 11 & 26.0 & 120 & Lithuania \\
\hline 11 & 25.2 & 121 & Albania \\
\hline 11.2 & 11.3 & 122 & Cuba \\
\hline 11.4 & 15.5 & 123 & Slovakia \\
\hline 11.5 & 22.2 & 124 & Singapore \\
\hline 11.6 & 14.7 & 125 & Costa Rica \\
\hline 11.7 & 14.6 & 126 & Hungary \\
\hline 11.7 & 10.6 & 127 & Montenegro \\
\hline 11.9 & 6.3 & 128 & Brunei \\
\hline 12 & 25.5 & 129 & Argentina \\
\hline 12 & 30.9 & 130 & Chile \\
\hline 12.1 & 30.6 & 131 & Poland \\
\hline 12.2 & 20.5 & 132 & Estonia \\
\hline 12.3 & 37.9 & 133 & USA \\
\hline 12.4 & 46.4 & 134 & Portugal \\
\hline 12.7 & 41.5 & 135 & Cyprus \\
\hline 12.8 & 39.4 & 136 & Malta \\
\hline 12.8 & 46.3 & 137 & Czech Republic \\
\hline 12.8 & 46.4 & 138 & Luxembourg \\
\hline 12.9 & 26.6 & 139 & Greece \\
\hline 12.9 & 65.7 & 140 & Austria \\
\hline 13 & 29.4 & 141 & Belgium \\
\hline 13.1 & 61.0 & 142 & Finland \\
\hline 13.2 & 19.7 & 143 & Spain \\
\hline 13.3 & 39.2 & 144 & France \\
\hline 13.3 & 14.3 & 145 & Italy \\
\hline 13.3 & 27.1 & 146 & UK \\
\hline 13.6 & 45.5 & 147 & Sweden \\
\hline 13.6 & 42.8 & 148 & Denmark \\
\hline 13.6 & 21.3 & 149 & South Korea \\
\hline 13.6 & 30.0 & 150 & Ireland \\
\hline 13.7 & 31.6 & 151 & Germany \\
\hline 13.8 & 21.3 & 152 & Israel \\
\hline 13.9 & 18.6 & 153 & Netherlands \\
\hline 14 & 34.9 & 154 & Japan \\
\hline 14.1 & 36.6 & 155 & Canada \\
\hline 14.1 & 29.5 & 156 & Norway \\
\hline 14.2 & 10.2 & 157 & New Zealand \\
\hline 14.3 & 30.4 & 158 & Switzerland \\
\hline 14.3 & 60.5 & 159 & Iceland \\
\hline 14.4 & 21.2 & 160 & Australia \\
\hline 14.4 & 35.3 & & \\
\hline 14.6 & 24.3 & & \\
\hline
\end{tabular}

$\Psi \Delta t, \quad D_{A}$

$14.9 \quad 46.2$

$14.9 \quad 57.5$

$15 \quad 31.9$

$15.1 \quad 3.4$

$15.1 \quad 51.5$

$15.5 \quad 9.1$

$15.6 \quad 32.6$

$15.8 \quad 48.4$

$15.9 \quad 54.9$

$15.9 \quad 47.7$

$16 \quad 61.0$

$16.1 \quad 61.2$

$16.3 \quad 33.1$

$16.4 \quad 40.9$

$16.4 \quad 41.6$

$16.4 \quad 34.9$

$16.7 \quad 56.1$

$16.8 \quad 39.9$

$16.9 \quad 14.8$

$17 \quad 35.4$

$17.2 \quad 54.7$

$17.2 \quad 35.8$

$19.1 \quad 50.6$

$19.1 \quad 61.3$

$19.2 \quad 74.1$

$19.6 \quad 104.3$

$19.8 \quad 79.1$

$20 \quad 70.0$

$20.7 \quad 51.9$

$20.9 \quad 62.7$

$21.5 \quad 115.9$

$21.6 \quad 95.5$

$21.7 \quad 111.5$

$21.9 \quad 121.6$

$22.6 \quad 123.0$

$22.8 \quad 98.9$

$22.9 \quad 149.9$

$23 \quad 92.3$

$23.3 \quad 98.2$

$23.3 \quad 69.9$

$23.3 \quad 69.5$

$23.6 \quad 60.2$

$23.7 \quad 95.5$

$23.8 \quad 55.9$

$23.9 \quad 80.7$

$24 \quad 176.7$

$24 \quad 58.9$

$24.4 \quad 91.6$

$24.6 \quad 57.9$

$24.9 \quad 99.1$

$\begin{array}{ll}25 & 72.7\end{array}$

$25.7 \quad 62.4$ 


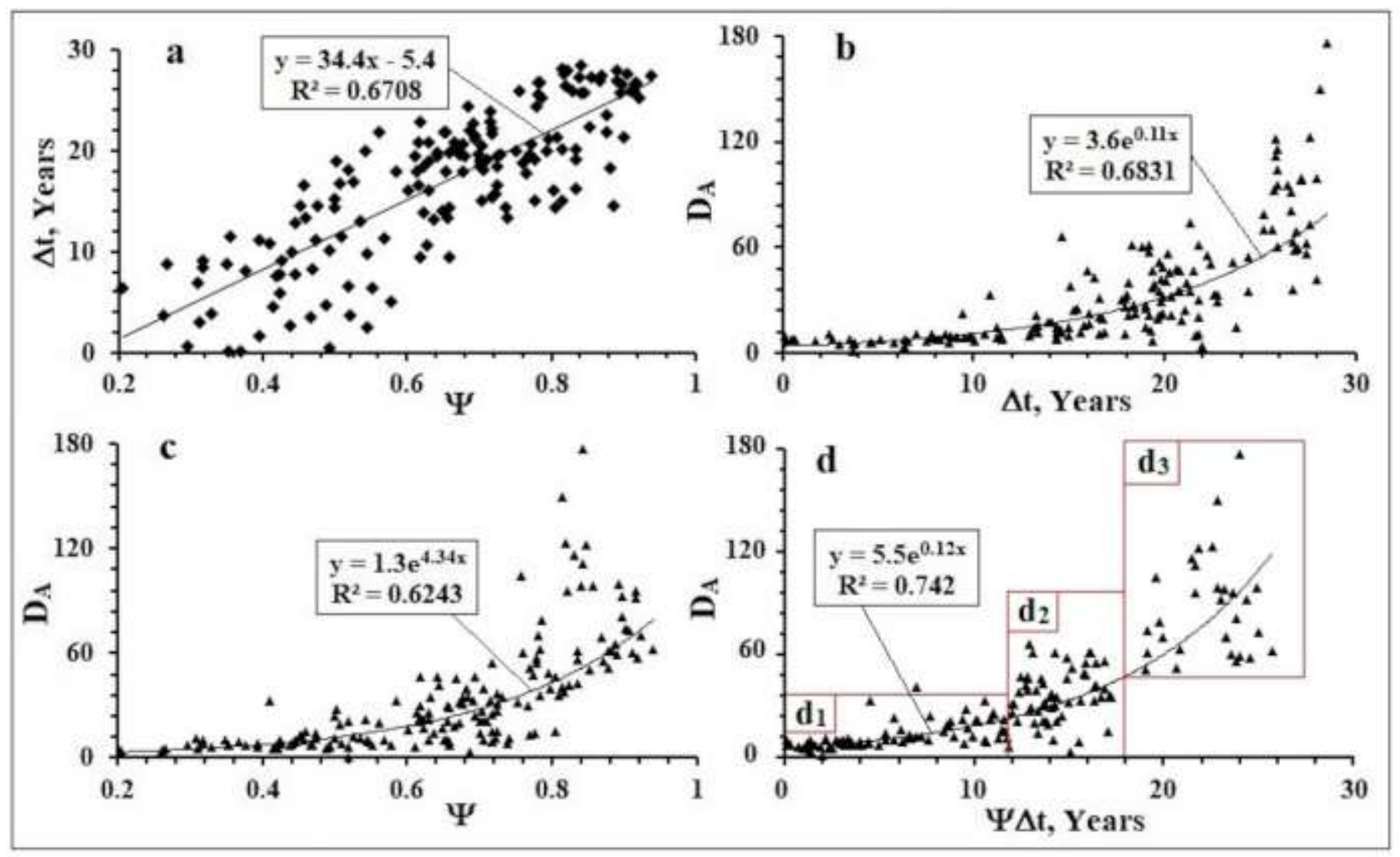

Figure 3. The dependence of the average lifetime after 55 years $(\Delta t)$ on the education index ( $\Psi)$ for different countries $(a)$ and exponential approximations of dependencies of the mortality rate $\left(D_{A}\right)$ for different countries on $\Delta t(b),(c)$ and $\Psi \Delta t(d)$. The rectangles are the countries that are intellectually and economically underdeveloped $\left(d_{1}\right)$, moderately developed $\left(d_{2}\right)$ and highly developed $\left(d_{3}\right)$. Baseline data for countries from [1].

From (1) it follows that $\mathrm{D}_{\mathrm{A}}$ will be proportional to the exponential $\exp (\mathrm{k} \Psi \Delta \mathrm{t})$. Figure 3 shows that the dependences of $\mathrm{D}_{\mathrm{A}}$ on $\Psi, \Delta \mathrm{t}$ and $\Psi \Delta \mathrm{t}$ are well approximated by the exponents, and the coefficient of confidence of the approximation $\left(\mathrm{R}^{2}\right)$ has the greatest value with the exponent $\Psi \Delta \mathrm{t}$. The corresponding exponents are applicable for approximations of dependences of the prevalence of $\mathrm{AD}$ and $\mathrm{D}_{\mathrm{A}}$ on the age categories of patients in different countries $[1,4,9]$. 


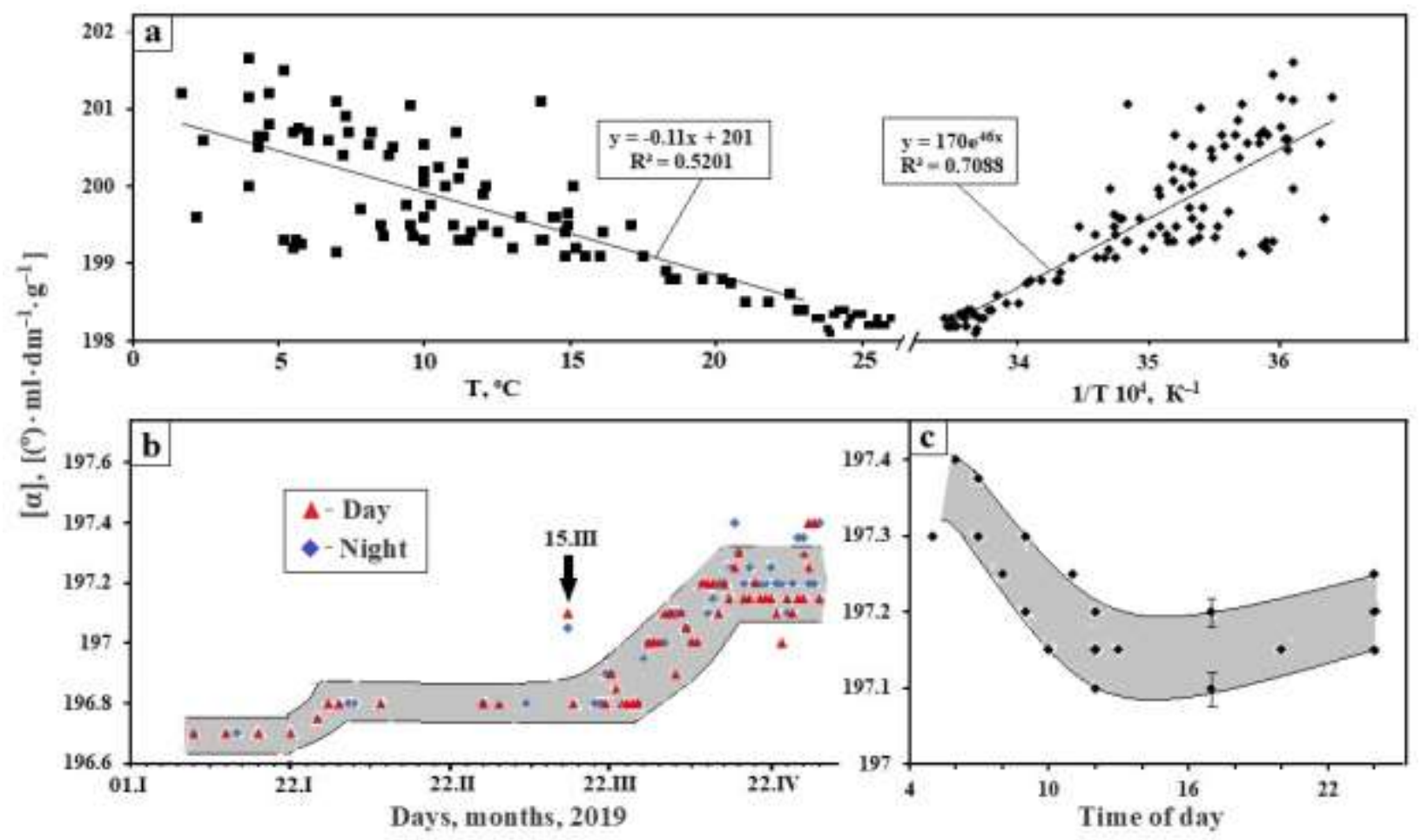

Figure 4. (a) Dependence of the specific rotation $[\alpha]\left(\left[\left(^{\circ}\right) \mathrm{ml} \mathrm{dm}^{-1} \mathrm{~g}^{-1}\right]\right)$ of an aqueous solution of dextran on T and $1 / T$ (Arrhenius approximation), from [32]. (b) Dependence [ $\alpha$ ] in the period from 04. I.2019 - 30.IV.2019, the arrow indicates the values [ $\alpha$ ] with the index of magnetic activity $K_{p}=6$ (15.III.2019). (c) Daily variations [a] in the period 10.IV-01.05 2019. Toned areas of fluctuations of the measured values $[\alpha][32]$.

The dependence of the specific rotation $[\alpha]$ (optical activity) of the dextran aqueous solution on temperature and its daily and inter-seasonal monitoring are shown in Figure 4. The arrow in Figure 4b marks the date of March 15, 2019, when the geomagnetic field activity index $\left(\mathrm{K}_{\mathrm{P}}\right)$ during the measurement $[\alpha]$ reached the value of 6 . Estimation of the activation energy $\left(E_{A}\right)$, obtained from the Arrhenius approximation of the dependence of $[\alpha]$ on $\mathrm{T}$ for a dextran solution, gave a value of $0.38 \mathrm{~kJ} / \mathrm{mol}$, close to EA for physiological glucose solution - $0.33 \mathrm{~kJ} / \mathrm{mol}[32]$ and comparable to by size excitation energy of the first rotational state of the $\mathrm{H} 2 \mathrm{O}$ orthoisomer $(0.28 \mathrm{~kJ} / \mathrm{mol})$ [33].

\section{Discussion}

From data analysis of the Tables and approximations of the distribution by country of the global mortality rate from $\mathrm{AD}\left(\mathrm{D}_{\mathrm{A}}\right)$ and intellectual potential $(\Psi \Delta \mathrm{t})($ Figure 1, Figure 
3), it follows that both demographic characteristics depend on the level of economic development of countries, and $\mathrm{D}_{\mathrm{A}}$ exponentially depends on $\Psi \Delta \mathrm{t}$. The ranking of countries on the rise $\Psi \Delta \mathrm{t}$ led to the division of countries according to the level of intellectual and economic development into three groups, which in coordinates $\mathrm{D}_{\mathrm{A}}$ and $\Psi \Delta \mathrm{t}$ in Figure $2 \mathrm{~d}$ form three zones, highlighted by rectangles $d_{1}(1-75), d_{2}$ (76-131) and $d_{3}(132-160)$, in brackets the numbers of countries in the Table. These zones correspond to the division of countries of the world according to economic criteria for weak $\left(\mathrm{d}_{1}\right)$, medium $\left(\mathrm{d}_{2}\right)$ and highly developed $\left(\mathrm{d}_{3}\right)$. There are no sharp boundaries on the $\Psi \Delta \mathrm{t}$ coordinate between the $d_{1}$ and $d_{2}$ countries of the groups, but they have significantly less intellectual potential and $D_{A}$ than those of the $d_{3}$ countries. The average values of $\Psi \Delta t$ in $d_{1}, d_{2}$ and $d_{3}$ groups grow in an arithmetic progression - 5.9; 14.4; 22.5 years, and $\mathrm{D}_{\mathrm{A}}$ in geometrical - 12.7; 36.5; 87.1 per 100,000 population.

Large values of $D_{A}$ in the $d_{3}$ group can be associated with the civilizational, mental risk factor of $\mathrm{AD}$, which is based on discrepancies between the professions of the postindustrial epoch and the level of mental development of workers. For some professions, a person may not have the necessary education and natural abilities, and the performance of others, on the contrary, suppresses his mentality. Both situations are fraught with chronic stress, which leads to the degradation of cognitive functions and harmful changes in the brain $[34,35]$. Such changes can easily occur in the brain of a child, which is immature up to 10-12 years old [36], if scientifically unfounded technologies are used in the process of learning. For example, in Japan children are required to learn the left hemisphere syllable alphabet in combination with the right-hemispheric hieroglyphics before school and in primary school [37]. At the same time, inevitable distortions of the natural functional specialization of the brain hemispheres can subsequently provoke and strengthen the effects of the mental risk factor of $\mathrm{AD}$, which ultimately leads to an increase in $\mathrm{D}_{\mathrm{A}}$ in Japan to a record value in the $\mathrm{d}_{3}$ group. For comparison, in China, teaching hieroglyphic literacy is not as accelerated as in Japan and, accordingly, $\mathrm{D}_{\mathrm{A}}$ in China is three times less than in Japan. 
The high efficiency of the sapientation process of countries of the $\mathrm{d}_{3}$ group, located, as a rule, in the zone above $35-40^{\circ} \mathrm{s}$. sh. in [11], they were associated with a low level of their insolation and average annual temperature, as well as with a high efficiency of the effect of CF during the night and early morning [13, 14, 38, 39, 40]. In $\mathrm{d}_{1}$ countries, the relationship between these climatic and solar factors is reversed, which explains the low $\Psi \Delta \mathrm{t}$ and DA values in these countries compared with the $\mathrm{d}_{3}$ group countries. The physical nature of $\mathrm{CF}$ is not known, a priori endows it with helicity and high penetrating power, which is not inherent in the corpuscular and electromagnetic radiation of the Sun. In principle, solar neutrinos possess such properties, however, its physical nature still remains an unsolved problem of the physics of elementary particles [41]. It is believed [38] that CF activates the processes of self-organization in water-containing cooperative biosystems containing homogeneous chiral molecules or molecular complexes. For the intensity of the solar neutrino flux of the beryllium cycle, an annual rhythm was revealed [42], due to the difference in distance between the Sun and the Earth in winter and summer.

The increase in $[\alpha]$ value of dextran saline after March 22 (Figure 4b) correlates with the process of spring awakening of plants and confirms the hypothesis of the participation of $\mathrm{CF}$ in the metabolism of living organisms. The effect of $\mathrm{CF}$ can be explained by numerous observations of the anomalous productivity of living organisms and, above all, living in the aquatic environment (Figure 5) [10, 40]. Correlations of diurnal changes $[\alpha]$ (Figure 4c) and blood concentrations of cortisol, sugar and melatonin (Figure 2) indicate an increase in CF activity at night. In addition to the time factor and violations of the night sleep mode, the activity of the $\mathrm{CF}$ will be influenced by geographical parameters (latitude, composition of the lithosphere, hydrosphere). 


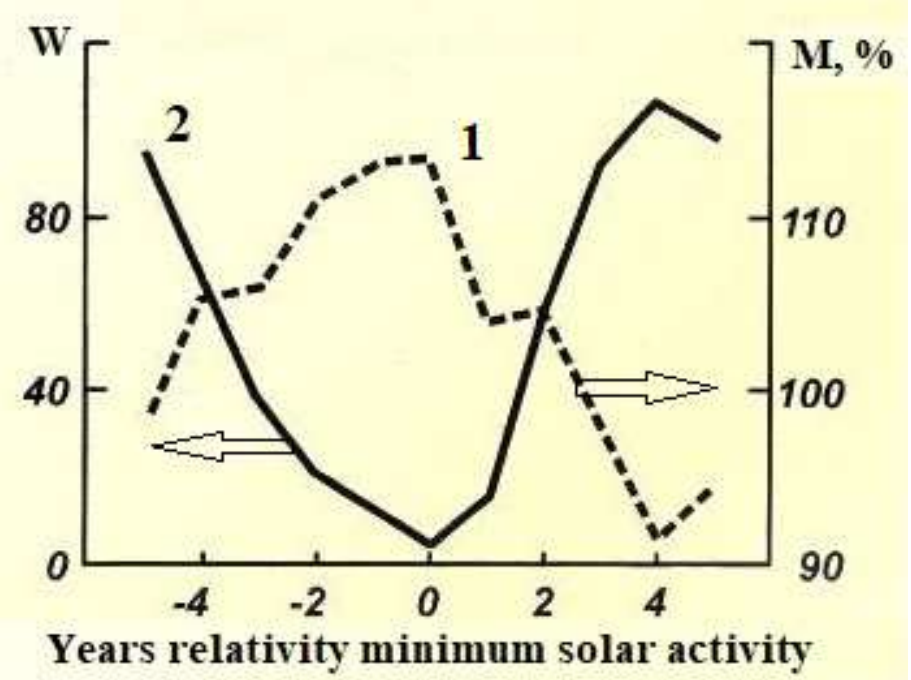

Figure 5. Grayan's mussel growth $(M, \%)$ in the northwestern part of the Sea of Japan (1), W is the number of sunspots during the minimum years of its activity (W) from [10].

Cooperative effects in biosystems, and hence their sensitivity to $\mathrm{CP}$, depend significantly on the $\mathrm{T}$ of the human body and brain (Figure 2). An important role in the cognitive functions of the brain is played by metabolic processes in the structures of the frontal-temporal lobes [36]. The kinetics of these processes depends on stationary $\mathrm{T}$ [43], the value of which is determined by the intensity of metabolic processes and the rate of removal of excess heat from the brain by venous blood and the bones of the skull. The latter process effectively proceeds through the bones of the inner walls of the paranasal sinuses of the skull, since they are ventilated with inhaled air having a $\mathrm{T}$ external environment. With its decrease at night and slowing down of metabolic processes in sleep, the brain's $\mathrm{T}$ decreases by $\sim 1{ }^{\circ} \mathrm{C}$ [43]. It follows that the stationary $\mathrm{T}$ of the frontal lobes of the aborigines of countries of the $d_{1}$ group may be higher by tenths of a degree [43] than among the aborigines of the countries of the $\mathrm{d}_{3}$ group. This difference in $\mathrm{T}$ will affect the metabolism of cognitive functions and the quantum effects in the fluidic media of the brain, ensuring its response to the effects of CF [12, 33, 43]. Normally and pathologies, brain fluid systems contain glucose, amino acids and amyloid protein precursors [44, 45, 46]. The effect of $\mathrm{CF}$ and a decrease in brain $\mathrm{T}$ during a night's sleep can trigger the association of glucose, amino acids [32, 46, 47] and the aggregation of precursor proteins 
into amyloid plaques and fibrils [46, 48]. Changes in the balance of right-left amino acids in the fluid systems of the brain [49] under the influence of CF and temperature can lead to mutations of the genes responsible for the metabolism of amyloid protein [4].

\section{Conclusion}

The demographic analysis of statistical data on mortality from AD showed that, in the post-industrial epoch, the inadequate realization of the human mentality in the process of professional activity becomes a significant epidemiological risk factor for AD. Herewith in developing countries a lack of competence prevails, and in highly developed countries, it may be supplemented by the suppression of the natural abilities of a person by work in the service sector. В обоих случаях будет травмироваться психофизика человека и возникать необратимые деформации нейрофизиологии когнитивных функций, которые в пожилом возрасте могут спровоцировать развитие AD. In both situations, the human psyche will be traumatized and irreversible deformations of the neurophysiology of cognitive functions will occur, which in old age can provoke the development of $\mathrm{AD}$. This mechanism of action of the mental risk factor $\mathrm{AD}$ is confirmed by the exponential dependence of its distribution on the education index of countries The geography of the mortality rate from $\mathrm{AD}$ agrees well with the difference in the effectiveness of the chiral solar and temperature factors on the physiology of the cognitive abilities of the Aboriginal countries of the North and South.

\section{Literature}

1. GBD 2016 Dementia Collaborators, Global, regional, and national burden of Alzheimer's disease and other dementias, 1990-2016: a systematic analysis for the Global Burden of Disease Study 2016, The Lancet Neurology. 2019, 18(1). Pp.88-106, https://doi.org/10.1016/S1474-4422(18)30403-4

2. Zakharov V.V., Vakhnina N.V., Gromova D.O., Tarapovskaya A.A. Review of materials of the international conference on Alzheimer's disease, Washington, 18-23 of July, 2015, Neurological J. 2015; 20 (6): pp. 65-69. DOI: http://dx.doi.org/10.18821/1560-9545-2015-20-6-65-69

3. Koberskaya NN. Current views of the risk factors, diagnosis, and therapy of Alzheimer's disease (according to the proceedings of the Alzheimer's Association International Conference, London, 2017). 
Neurology, neuropsychiatry, psychosomatics. $\mathbf{2 0 1 7} ; \quad$ 9(3): $\quad$ pp. $\quad 81-87 . \quad$ DOI: http://dx.doi.org/10.14412/2074-2711-2017-3-81-87

4. Ertekin-Taner, N. Genetics of Alzheimer disease in the pre- and post-GWAS era. Alzheimer's Research \& Therapy. 2010. 2:3. $\quad$ https://doi.org/10.1186/alzrt26, URL: https://alzres.biomedcentral.com/articles/10.1186/alzrt26

5. Xu, W., Ferrari, C., Wang, H.-X. Epidemiology of Alzheimer's Disease, Understanding Alzheimer's Disease, Inga Zerr, Intech Open, 2013, DOI: 10.5772/54398. URL: https://www.intechopen.com/books/understanding-alzheimer-s-disease/epidemiology-of-alzheimer-sdisease

6. Rizzi,L., Rosset,I., Roriz-Cruz, M. Global Epidemiology of Dementia: Alzheimer's and Vascular Types. Biomed Res Int. 2014; 2014: 908915. $\quad \underline{\text { http://dx.doi.org/10.1155/2014/908915 }}$ https://www.ncbi.nlm.nih.gov/pmc/articles/PMC4095986/

7. Eiser, A.R. Why Does Finland Have the Highest Dementia Mortality Rate? Environmental Factors May Be Generalizable, Brain Research, 2017, http://dx.doi.org/10.1016/j.brainres.2017.06.032

8. World Health Rankings: Alzheimer's/dementia. http://www.worldlifeexpectancy.com/cause-ofdeath/alzheimers-dementia/by-country/

9. Ono, K. et al. Apparent Increases in Age-Specific Morbidity and Mortality of Alzheimer's Disease in Japan. EC Neurology. 2019, 11.1, pp. 38-45. https://ecronicon.com/ecne/pdf/ECNE-11-00456.pdf

10. Vladimirsky B.M., Temuryants N.A. The effect of solar activity on the biosphere-noosphere. Heliobiology from A.L. Chizhevsky to the present day. M. MNEPU, 2000, 374 p.

11. Kholmanskiy, A. S., Nurgaliev, I. S., Strebkov, D. S. Sapientation process energy. Economic strategy, 2018, 7, pp. 118-125.URL: http://www.inesnet.ru/summary/sapientation-process-energy/; http://newidea.kulichki.net/pubfiles/181129133738.pdf

12. Kholmanskiy, A.; Zaytseva, N. Physically adequate approximations for abnormal temperature dependences of water characteristics. J. Mol. Liq. 2019, 275, pp. 741-748. DOI: https://doi.org/10.1016/j.molliq.2018.11.059 .

13. Kholmanskiy, A.S. Dependence of the resource of functional asymmetry of the brain on external conditions. The galactic factor of spiritual evolution. Asymmetry. 2009, 3 (1), pp. 51-71. URL: http://cerebral-asymmetry.narod.ru/Asymmetry_1_2009.pdf

14. Kholmanskiy, A., Zaytseva, N. Chiral Factor of Circadian Rhythm of Human Physiology, Int. J. Res. Pharm. Biosci. 2018, 5(4) pp. 6-10. URL: https://www.ijrpb.org/papers/v5-i4/2.pdf 
15. Shokri-Kojori, E.. Wang, G.-L., Wiers,C.E. et al. $\beta$-Amyloid accumulation in the human brain after one night of sleep deprivation. PNAS, 2018, $115 \quad$ (17), pp. 4483-4488; https://doi.org/10.1073/pnas.1721694115

16. Beil, L. The brain may clean out Alzheimer's plaques during sleep. Science news, 2018, 194(2), p. 22, URL: https://www.sciencenews.org/article/sleep-brain-alzheimers-plaques-protein

17. Blask, D.E., Dauchy, R.T., Sauer, L.A., et al. Light during darkness, melatonin suppression and cancer progression. Neuroendocrin. Let. 2002; 23(2), pp.52-56.

18. van Someren, E.J., Mirmiran, M., Swaab, D.F. Non-pharmacological treatment of sleep and wake disturbances in aging and Alzheimer's disease: chronobiological perspectives. Behavioural Brain Res. 1993. 57 (2): 235-53. doi:10.1016/0166-4328(93)90140-L

19. Omonigho, M. et al. Sleep, Cognitive impairment, and Alzheimer's disease: A Systematic Review and Meta-Analysis. Sleep. 2017, 40, http://dx.doi.org/10.1093/sleep/zsw032 .

20. Suwazono Y et al. Longitudinal study on the relationship between alternating shift work and the onset of diabetes mellitus in male Japanese workers. J. Occupational and Environmental Med. 2006; 48(5): pp. 455-461. http://dx.doi.org/10.1097/01.jom.0000214355.69182.fa

21. Xia, Y. et al. Night Shift Work Increases the Risks of Multiple Primary Cancers in Women: A Systematic Review and Meta-analysis of 61 Articles. Cancer Epidemiology, Biomarkers \& Prevention. 2018. http://cebp.aacrjournals.org/content/27/1/25.

22. Jiao, L. et al. "Sleep duration and incidence of colorectal cancer in postmenopausal women." $B r . J$. Cancer. 2013. 108(1): pp. 213-221 doi: 10.1038/bjc.2012.561,

23. Parent, M., El-Zein, M., Rousseau, M. et al. Night Work and the Risk of Cancer Among Men. Am. J. Epidemiology, 2012, 176(9), pp. 751-759, https://doi.org/10.1093/aje/kws318

24. Ismail,R., Hansen, A.K., Parbo, P. et al. The Effect of 40-Hz Light Therapy on Amyloid Load in Patients with Prodromal and Clinical Alzheimer's Disease. Int. J. Alzheimer's Disease, 2018, Article ID 6852303, 5 p. https://doi.org/10.1155/2018/6852303.

25. Thomson, H. How flashing lights and pink noise might banish Alzheimer's, improve memory and more. Nature, 2018, 555, pp. 20-22, http://dx.doi.org/10.1038/d41586-018-02391-6.

26. Kholmanskiy, A.S., Minakhin A.A. Phylogeny factors of posture and morphogenesis of the human brain. Sciences. 2012. 4, P. 1-8. URL: http://naukovedenie.ru/PDF/48pvn412.pdf

27. Kholmanskiy, A.S., Minakhin, A.A. Interconnection of electrical oscillations of the heart and brain. Bull. St.-P. State Univ. Med. $\mathbf{2 0 1 8 , 1 3 ( 2 )}$ pp. $117-135$. https://dspace.spbu.ru/bitstream/11701/10429/1/01-Kholmansky.pdf 
28. The population of the countries of the world for 2016. URL. http://total-rating.ru/1574-chislennostnaseleniya-stran-mira-na-2016-god.html

29. Ranking of countries by level of education. Humanitarian encyclopedia: Research. Center for humanitarian technologies, 2019. https://gtmarket.ru/ratings/education-index/education-index-info

30. WHO. Life expectancy and Healthy life expectancy. Data by country. URL: http://apps.who.int/gho/data/node.main.688?lang=en; Average life expectancy in Russia and the world in 2018. bs-life.ru. URL. http://bs-life.ru/makroekonomika/prodolzitelnost-zizni2013.html

31. Chandra, V., Ganguli, M., Pandav, R. et al. Prevalence of Alzheimer's disease and other dementias in rural India: the Indo-US study. Neurology. 1998; 51: pp.1000-1008. DOI: 10.1212/WNL.51.4.1000. 32. Kholmanskiy, A. Chirality anomalies of water solutions of saccharides. J. Mol. Liq 2016, 216, pp. 683-687. http://dx.doi.org/10.1016/j.molliq.2016.02.006

33. Pershin, S.M. Ortho/Para $\mathrm{H}_{2} \mathrm{O}$ Conversion in Water and a Jump in Fluidity of Erythrocytes through a Microcapillary at the Temperature 36.6+/- $0.3{ }^{\circ} \mathrm{C}$. Phys. Wave Phenomena, 2009, 17(4), pp. $241-250$. 34. Karp, A., Andel, R., Parker, M.G. et al. Mentally Stimulating Activities at Work During Midlife and Dementia Risk After Age 75: Follow-Up Study From the Kungsholmen Project. American J. Geriatric Psychiatry. 2009;17(3):227-36, doi: 10.1097/JGP.0b013e318190b691. URL: https://www.ncbi.nlm.nih.gov/pubmed/19454849

35. Then, F.S. Aranda, M.P. Vega, W.A. How Your Work Can Reduce Your Dementia Risk. USC Edward R. Roybal Institute on Aging. 2017. DOI:10.13140/RG.2.2.12701.51685, URL: https://roybal.usc.edu/how-your-work-can-reduce-your-dementia-risk/

36. Bezrukikh, M.M., Sonkin, V.D., Farber, D.A. Developmental physiology: (Physiology of child development). 2003. M. Academy, 416 p. ISBN 5-7695-0581-8. URL: http://www.al24.ru/wpcontent/uploads/2013/08/без_1.pdf

37. Ivanov, V. V. Selected works on semiotics and history of culture. 1999. Vol.1. M. 912 p. ISBN 57859-0073-4.

38. Kholmanskiy, A.S. Activation of biosystems by an external chiral factor and a decrease in temperature. Asymmetry. 2018, 12(3) pp. 64-77. DOI:10.18454/ASY.2018.3.16317 URL: http://www.cerebral-asymmetry.ru/Asymmetry_12_3_2018.pdf.

39. Kholmanskiy, A.S. Chirality and quantum effects as factors of morphogenesis. Electron. Math. Med.-

Biol. J. 2010. 9(4) URL: http://www.sci.rostelecom67.ru/user/sgma/MMORPH/N-28html/kholmanskiy-2/kholmanskiy-2.htm

40. Chernoschekov K.A., Lepekhin A.V. Materialization of the ideas of A.L. Chizhevsky in epidemiology and microbiology. Tomsk: TSU, 1993. 273 p. 
41. Giunti C., Studenikin A. Neutrino electromagnetic interactions: a window to new physics. Rev. Mod. Phys. 2015. 87.531. DOI: $10.1103 /$ RevModPhys.87.531

42. M. Agostini et al. (Borexino Coll.), Seasonal Modulation of the 7Be Solar Neutrino Rate in Borexino, Astropart.Phys. 2017, 92, pp. 21-29, arXiv:1701.07970.

43. Wang, H., Wang, B., Normoyle, K.P. et al. Brain temperature and its fundamental properties: A review for clinical neuroscientists. Front. Neurosci.,

2014. 8(307) https://doi.org/10.3389/fnins.2014.00307.

44. Weinstein, G., Maillard, P., Himali, J.J. et al. Glucose indices are associated with cognitive and structural brain measures in young adults. Neurology. 2015;84(23):2329-2337. doi:10.1212/WNL.0000000000001655; URL: https://n.neurology.org/content/84/23/2329

45. Fisher, G., Lorenzo, N., Abe, H. Free D- and L-amino acids in ventricular cerebrospinal fluid from Alzheimer and normal subjects. Amino Acids. 1998. 15(3): pp. 263-269

46. Yakhno, N. N. Dementia: a guide for doctors. 2010. M. 2010. 272 p. ISBN 5-98322-449-5

47. Weili Xu, W., Qiu, C., Gatz, M. et al. Mid- and Late-Life Diabetes in Relation to the Risk of Dementia. Diabetes, 2009, 58(1): pp. 71-77, .https://doi.org/10.2337/db08-0586 .

48. Structure formation in chiral systems. Supramolecular strings. Ed. V.A. Tverdislov. M. 2016.312 p. ISBN 978-5-8279-0137-2. https://link.springer.com/article/10.1007\%2FBF01318865 .

49. Chervyakov A.V. Violation of molecular asymmetry of amino acids (D\L-enantiomers) during normal aging and neurodegenerative diseases. Asymmetry. 2010. 2. URL: http://cerebralasymmetry.ru/2_10.pdf 